\title{
Regional approaches in high-rise construction
}

\author{
O.G. Iconopisceva ${ }^{1}$, G.A. Proskurin $^{1 *}$ \\ Orenburg State University, 460018, Orenburg, prospect Pobedy, 13, Russia
}

\begin{abstract}
The evolutionary process of high-rise construction is in the article focus. The aim of the study was to create a retrospective matrix reflecting the tasks of the study such as: structuring the most iconic high-rise objects within historic boundaries. The study is based on contemporary experience of high-rise construction in different countries. The main directions and regional specifics in the field of high-rise construction as well as factors influencing the further evolution process are analyzed. The main changes in architectural stylistics, form-building, constructive solutions that focus on the principles of energy efficiency and bio positivity of "sustainable buildings", as well as the search for a new typology are noted. The most universal constructive methods and solutions that turned out to be particularly popular are generalized. The new typology of high-rises and individual approach to urban context are noted. The results of the study as a graphical scheme made it possible to represent the whole high-rise evolution. The new spatial forms of high-rises lead them to new role within the urban environments. Futuristic hyperscalable concepts take the autonomous urban space functions itself and demonstrate us how high-rises can replace multifunctional urban fabric, developing it inside their shells.
\end{abstract}

\section{Introduction}

It's impossible nowadays to imagine the world without high-rises, which is the mainstream in the forming of high dense urban landscapes. Since 2000 the number of buildings above $200 \mathrm{~m}$ has grown in the world by $325 \%$. According to annual research of the CTBUH 2011 and 2014 were the record for the number of completed skyscrapers. In 2016 there were 3720 high-rise buildings in the world (height above $150 \mathrm{~m}$ ), 110 of them "supertall" and 1153 - above 200m. Today's high-rise leader is China with $66 \%$ of all buildings $200+$ over the world [1]. In this study the generalized analysis of high-rise construction is represented according to timeline divided by well-known key evolutionary stages. It allows us to note the features and typology diversity.

High-rises of the $21^{\text {st }}$ century are high-tech intellectual objects. Energy efficient technologies developed in high-rise construction explain its extravagant sculptural plastics, complex surface design and individual space-planning solutions. Archphytomelioration transforms high-rises into oases, which different them on a qualitative new typological and structural level from the $20^{\text {th }}$ century high-rise architecture.

\footnotetext{
* Corresponding author: georgepro@yandex.ru
} 
The presented material is based on the data of the CTBUH [1-10] and the work of the world-famous bureaus like Skidmore, Owings \& Merill (SOM), Foster and Partners (F\&P), Office for Metropolitain Architecture (OMA), Zaha Hadid (ZH), Llewelyn Davies (LD), T. R. Hamzah \& Yeang Sdn Bhd, Stefano Boeri Architetti (SBA), Studio Liebeskind (SL), Adrian Smith+Gordon Gill Architecture, Herzog \& de Mueron, MVRDV, SLCE Architects, Eric Parry Architects, Gensler, UNStudio , P\&T Group, NBWW, Perkins+Will, Emaar Properties, Kohn Pedersen Fox Associates (KPF), Hariri Pontarini Architects, IAD, BSB, Wilkinson Eyre Architects, Archgroup Consultants, BFLS, Oiio, Hufton+Crow , NBBJ, MAD.

Materials of scientists and researchers in the field of high-rise and energy-efficient construction K. Yeang, S. Boeri, [2], K. Al-Kodmany are discussed in the article as well as N. Foster, S. Luff, D. Visco, M. Keeler, B. Burke, J. Wines.

Russian scientists who study the high-rise urban, architectural and structural features in Russia and abroad - T.G. Maklakova, Y.G. Granik, V.P. Generalov, E.M. Generalova, Y.A. Tabunschikov, M.M. Brodach, N.V. Shilkin, A.N. Tetior. Materials of 'Tall Buildings' magazine are in use within the article as well as data of the Museum of High-Rises and web resources dedicated the high-rise features.

\section{Methods}

The article contains complex analysis of the high-rise evolution. Graph-analytical method allows to differentiate the study tasks clearly. And the material divided by three key periods and each structured by the global region.

$1^{\text {st }}$ Period. The Origin. 1880s-1930s.

The urban conditions of Manhattan determined the high-rise origin - the brightest achievement of construction of the $20^{\text {th }}$ century. In this period the classical structure and image of skyscraper were formed within rationalism and Art Deco. The iconic objects are Empire State Building, 1931, arch. Shreve, Lamb and Harmon; Chrysler Building, 1930, arch. W. Van Alen; Rockefeller Center, 1933, arch. R. Hood. etc.

$2^{\text {nd }}$ Period. 1950s - mid. 1990s. High-Rise Development as Multifunctional Centers. Since the middle of the $20^{\text {th }}$ century from Canada to South Africa the multifunctional highrise buildings being appeared such as Price Tower, 1956, arch. F.L. Wright; MetLife (Pan Am) Building, 1963, arch. W. Gropius, E. Roth, P. Belluschi; John Hancock Center, 1969, arch. SOM [2]. The rethinking of high-rise accents comes, as major, thanks to using curtain glass walls. In the 1960 s it was determined as "International style". The iconic objects were Lever House, 1952, arch. SOM [2]; UN Secretariat in New York, 1952, arch. O. Niemeyer, Le Corbusier, W. Harrison. In 1958 after the Seagram Building was built it became the golden standard in office real estate of the US. Since 1960s the structural solutions were radically changed because the invention and implementation of tubular and shell constructions [3]. The landmark objects were Renaissance Center in Detroit, 1977, arch. SOM; AT\&T Building in New York, 1984, arch. P. Johnson; Bank of America Plaza in Dallas, 1985, arch. JPJ Architects, HLM Design [4]; Lloyd of London, 1986, arch. R. Rogers. In the mid-1980s postmodernism gradually changed to high-tech. Skyscrapers of the mid-1980s are monumental and heavyweight. In the 1960s, the growth in the number of skyscrapers stopped. Up to the end of $20^{\text {th }}$ century the height of high-rises declined. At the end of the 1980 s the industrial and business transfer to Southeast Asia helped the beginning of high-rise development within these countries. Tubular and shell constructions enriched the architecture with tectonics.

Europe. In 1960s-1970s the urban concept of "integrated urbanism" and clear high-rise approach was formed. The principal feature of high-rise construction became the complexity and miltifunctionality as well as for business zones the exterritorial location out of historical 
centers. In 1950s the first business district was born of 20-30-story offices of "International Style" in Milan. In 1958 in Paris was adopted the plan of 'La Defence' business district [3]. In 1970s Defence - the geometrical architecture of glass and metal. Tour Elf, Tour Areva, Tour Gan, Tour Defence 2000, CNIT Building were the classical example of American business style. The construction of multifunctional Tour Montparnasse damaged the panoramic view of Paris. In 1980s in London the reconstruction of Docklands showed the creation of multifunctional urban environment with concentrated location on the north bank of Thames. In 1991 Canary Wharf $(245 \mathrm{~m})$ was built first, arch. C. Pelli being the tallest highrise building of tower-type in Europe [2]. The example of the complex approach to reconstruction by multifunctional high-rises in Germany is the development of financial district in Frankfurt-am-Main. The erection of high-rises above 60 floors in Europe continued till 1970s.

Russia. High-rise construction in USSR had the symbolic and ideological mission. In Soviet Russia the first buildings breaked mark of 100+ were the Stalin's Skyscrapers called "Seven Sisters". Among them was Kotelnicheskaya Embankment Building, 1952, arch. D. Chechulin, A. Rostkovsky. One year later the highest building in Moscow - the Main Building of Moscow State University (236m), arch. L. Rudnev. In 1967 the construction of New Arbat's Skyscrapers (below 100) was completed. In 1968 the 100m Hydroproject Building was built, then in 1970 - SEV Building (Comecon) - now the Moscow City Hall. Just another example of international style is Intourist Hotel, end 1960s, arch. M. Vinogradsky. In 1970s-1980s in Moscow 8 buildings 100+ in addition were built more. The House of Russian Government (102m), 1980, is noted among them.

Middle East. The beginning of high-rise development is the end of 1970s. In 1980-1990s the Dubai structure as a settlement included in fact two districts - "historical" center Deira and buildings along Sheikh Zayed Road, where were concentrated all the high-rises of office and multifunctional complexes. The first splash of high-rise construction in this region was at the end of 1970s - beginning of 1980s. The first skyscraper in Dubai the 39-story Dubai World Trade Center, 1979, arch. J. Harris, was adopted at once as the tallest in Middle East $(149 \mathrm{~m})$, set the further trend. Architecture of 1980 s was stand out with its faithfulness to postmodernism according to world trends.

$3^{\text {rd }}$ Period. 1990s-2017. New High-Rise Paradigms.

The changed architectural fashion flew the new aesthetic orients. By thy beginning of the $21^{\text {st }}$ century postmodern aesthetics transformed to neo-modern laconic and tech oriented trends. After the Energy crisis of 1974 the basic principle was to use energy-efficient technologies. The result of such development was the practice of "sustainable buildings" where the merge of architecture and energy-efficient technologies was reached [5-7]. The high-rises to be considered as energy-efficient and bio positive objects [8].

USA. 9 years passed after the Commerzbank in Germany the first "green" skyscraper was built in Manhattan. It was Hearst Tower, 2006, arch. F\&P. Frontage design used in large amount of skyscrapers by F\&P represents the diagonal mesh using modular energy-efficient glazing [9]. Bank of America Tower is considered the most green in the US. The Building works as giant air filter for Midtown Manhattan with its double-sided filtration system [10]. Urban conditions in Manhattan and the demand for luxury real estate near the Central Park led the way to new skyscraper types being introduced into super-dense development [11]. Like a point injection, ascetic "super-slenders" "punctured" urban fabric. Some of them have ratio of the base width to height $1 / 23$ [12]. The other one in a row of skyscraper typology is 'courtscraper' VIA 57 West, 2016, arch. BIG - a hybrid of traditional courtyard and highrise tower.

Europe. The principles of bioclimatic energy-efficient architecture were presented in 1997 by Commerzbank in Frankfurt-am-Main, arch. F\&P [13]. The building was the first 'green' skyscraper in the world and still the tallest in Europe till 2005. During the design 
process computer modeling and aerodynamic methods were used [7]. The principles of energy efficiency continue to realize - Main Tower, City Hall, Post Tower. N. Foster in the project of Swiss Re, 2004 in London moved to the system of round-hydrodynamic outlines. The building became the new city symbol and recognized as the best one of the decade. Foster's "Gherkin" idea was picked up by J. Nouvel in the bright "Torre Agbar", 2005, in Barcelona. But the Foster's ideas introduce slowly and office buildings with landscape bureau plan continue to erect all over the world. The landmark new generation bioclimatic object with the high-rise apartments is Bosco Verticale in Milan, 2014, arch. SBA [14]. It recognized the best skyscraper 100+ taking the International Highrise Award. This project opened the new perspectives for greening the skyscrapers and set an example for the development future cities.

China. The nowadays leader in mass, developing the whole cities. The individual iconic objects stand out of contemporary Chinese architecture in Beijing, Shanghai and Guangzhou. One of the first iconic was high-tech Chinese Bank in Hong Kong, 1985, arch. F\&P. Also the landmark is Jin Mao Tower [2] by SOM in Pudong, Shanghai. Its outline was inspired by the opening petals of lotus and imitates the length of the pagodas.

In 2008 the best building under the CTBUH rating was Shanghai World Financial Center by KPF, called 'the bottle opener' [15]. In 2010 the leader under energy-efficiency was supertall building with open-type engineering Pearl River Tower (309m) in Guangzhou by SOM [16]. Ping An Financial Center $(599 \mathrm{~m})$ by KPF is the tallest in Shenzhen, $2^{\text {nd }}$ tallest in China and the $4^{\text {th }}$ tallest in the world. Today the Shanghai Tower demonstrates the most faithfulness to common space in high-rise, which was built in 1997 for the first time. Shanghai Tower is the new prototype of high-rise building, the tallest in China, the $2^{\text {nd }}$ tallest in the world and the $3^{\text {rd }} 600+$ skyscraper within the "Megatall" category [17]. As early as 2018 the first vertical forest to be in China. It will be the Green Towers in Nanjing by SBA also designed on principles of Bosco Verticale. By 2021 S. Boeri to design in Liuzhou the whole series of high-rises vertical gardens within. It will be the new 'clever environment' and the answer to 'crazy city widening' in advanced but wasted China [18].

Australasia. By the mid. 1990s the high-rise buildings had the stepped structure and intricate top as usual - Republic Plaza (280m), 1995 in Singapore or Millenia Tower (223m), 1996, Capital Tower (254m), 2000, - composition of buildings eased as in United Overseas Bank Plaza One (280), 1992.

The major Taiwan's skyscraper Taipei 101, 2004, arch. C.Y. Lee \& Partners, with the national romantic forms is figuring in ultramodern materials. One of the international landmarks of the $20^{\text {th }}$ century expressed in general postmodern design were the Twin Towers of Petronas, 1996, arch. C. Pelli.

In Seoul, South Korea, Lotte World Tower is the $5^{\text {th }}$ tallest building in the world now.

Malaysian architect dr. Ken Yeang is the inventor of bioclimatic approach within the design of high-rises [19]. Over 10 buildings realized by himself with such features as vertical gardens - the buildings of new eco generation - Menara Mesiniaga, EDITT Tower, Putrajaya 2C5 in Singapore [20]. After this approach Marina Bay Sands in Singapore was erected as green landmark led to new typology of multidimensional high-rise structure $(200 \mathrm{~m})$, arch M. Safdie [21]. The giant object has three 55-story hotel towers connected by a roof terrace. The observation deck provides panoramic views.

The tallest Australian skyscraper is Q1 Tower (323m) in Gold Coast, 2005, arch. Atelier SDG. To date, in Brisbane is located the number of tallest buildings of this continent. Nowadays the primacy belongs to Infinity Tower (249m), 2013, arch. SOM. In 2014 CTBUH noted the One Central Park residential complex as the best high-rise of 2014. Apartments in Sydney by J. Nouvel is the major trend of future agriculture - the vertical farms within the city. Such an experimental farms in the courtyards and on the roofs of some residential and office buildings being exist $[22,23]$. 
Middle East. Since 2005 several city-forming district have emerged. Dubai Marina is 20 $\mathrm{km}$ from Deira, here there was a number of high-rises being erected, including Burj Khalifa. High-rises are the main attractors of the whole state. With such settings all the new skyscrapers must be the most of the most, the unique of the unique and irresistible in any parameters. Here different high-rise typology being erected claiming the primacy in many parameters or unique tech specs. The tallest residential building in the world is Infinity Tower. The tallest hotel Marriott Marquis $(355 \mathrm{~m})$ or the largest shopping center Dubai Mall. Unique buildings that made revolution in the field of high-rise, engineerings and urban planning as the Burj Khalifa (828m), arch. SOM, are marked by the CTBUH with the title of Global Icon. The competition to have the title of the tallest high-rise is being developing exactly in this region [24]. Spectacular in terms of attraction are kinetic elements on the facades of buildings and modular mesh coverings, as in Al-Bahar and Burj Qatar by J. Nouvel.

Russia. The first building 100+m in Russia was completed in 1995 - the Gazprom Tower in Moscow (150m). Outside Moscow, the first building of 100+ was Uralsib Bank's office, Ufa, 1999. By the $21^{\text {st }}$ century, there were $25100+$ buildings in Russia. Modern high-rise construction began after the 1998 crisis. The first new ones were three $115-\mathrm{m}$ towers of residential complexes at Leninsky Prospect in Moscow. Triumph Palace residential complex (264m), 2005, Naberezhnaya Tower (268m), 2007, City of Capitals complex (302m), 2009, Mercury City Tower (339 m), 2013, OKO complex (about 354m)... Now the highest in Russia and Europe is the Federation Tower (364 m), 2017, arch. nps+partner, Schweger Associated Architects. As a result, an area with ultra-high buildings appeared in Moscow, which is not found elsewhere in the world, except for the Dubai-Marina area. Nowhere else man build a 'wall to wall; higher than $300 \mathrm{~m}$. This fact reduces the quality of environment making impossible to fully inspect the interesting ones [25]. From Russian implemented buildings the CTBUH Awards received a residential building on Mosfilmovskaya Street, 2010, arch. S. Skuratov. In Yekaterinburg, the tallest symbols of the Ural region are the Iset Tower (209m), 2016, arch. W. Zobek, and the Vysotsky Tower (196m), arch. S. Bashkareva.

\section{Results}

The complexity of high-rise construction, increasing proportionally to the height, doesn't stop the geography of its spread. Each country is trying to form the image of the main regional as well as world center. Today high-rises are the new paradigms of urban life as an effort to solve the environmental problems. In countries with a high population density, high-rises are the solution to housing. In different countries the sum factors for the high-rise appearance is almost the same. The differencies are exactly in national self-identity, expressed in architectural image and relation to the context.

USA. Homeland of skyscrapers where the main stages of high-rise evolution were passed. The leadership with massiveness transferred to China and with uniqueness and advanced technologies to the Middle East. The existing urban super density and planning regulations helped to arise the new typologies of high-rises.

China. The high-rise leader with pace and massiveness. The search for a new typology is aimed at positioning the region as a global financial center, to find the solution of a complex ecological situation that doesn't exist anywhere else in the world and to provide super-dense population with living space. Australasia: The region has a wide range of typological diversity in high-rise construction, due to climatic conditions helping to upgrade the typology and to introduce the techs for eco buildings. The program of mass high-rise housing is being successfully implemented. Middle East. The region's economic strength and ambitious positioning in the world economic space is fixed in maximum and unique technological and architectural achievements in the field of high-rise construction. Climatic conditions 
determine the search for energy-efficient solutions. The region provided the world with innovations and paradigms of eco buildings.

Europe. The approach of 'integrated urbanism' dictates a complex and exterritorial development in high-rise construction. No race to build higher compensated by the development of advanced energy-efficient solutions and its rapid implementation to reduce dependence on external energy sources.

Russia. Up to the end of the $20^{\text {th }}$ century the high-rise objects were rarely, due to political reasons and no fixed place of the state within the global economy. High-rise objects appeared after Millennium are the effort to fix the country within the full-fledged participants within the world economy. The European selective approach and lack of regionalism are traced.

\section{Discussion}

The American urban planning practice, created the image of a high-rise business center, adjusts throughout the world according to urban conditions, positioning and strategy of the regions, national mentality. Urban landscapes in New York, similar to fields of stalagmites constantly growing up, continue to arise new typological and structural units. Super-slenders realize the ambitions, connected with the best 'window view' buying, and fix New York on the $2^{\text {nd }}$ position after Dubai as the tallest building owner. Attempts to enter the super dense fabric of Manhattan sometimes reach absurd concepts of hanging from asteroids high-rises, in which elementary human comforts are perceived as blasphemy.

In European cities, skyscrapers are an exception and there are some confrontations with a historical context that hardly admits large-scale neighbors. But it doesn't block the extravagant high-rise silhouettes appearance with its advanced tech solutions. In China, Middle East and Asian region, skyscrapers are actually the context, and confrontation with the environment is impossible. Race for height, especially in the Middle East, led to the term 'useless height'. So, the Burj Khalifa has $244 \mathrm{~m}$ of useless height, what might be an independent skyscraper. Nevertheless, the designers don't stop. Another problem is the balance of investments and the resulting dividends from ultra-high buildings. Sometimes streaming to uniqueness, economic expediency and common sense are lost. So Burj Khalifa was realized, both through the personal investments of the owner, and through the sale of real estates overlooking the tower in the surroundings [4].

Eco problems in high-rise megacities are trying to solve with the help of high-rise construction. In one case, compensating the lack of natural environment by vertical gardens, as S. Boeri suggests, calling modern megacities a 'true nightmare'. According to him architects nowadays thinking of what might be in cities without the greens hundred years after [14]. Such position may leads in near future to reduction of stylistic diversity in favor of architectural biopositivity in regions with strong eco troubles. S. Ban to erect high-rises using wood structures. James Law Cybertecture International creates the concept of a "cybertectural world" based on the symbolic balance between space and techs [26].

In other cases, the solution to over-urbanization is a concept of 'multidimensional city' [27]. Using the example of contemporary conceptual projects of Cloud Citizens, The Bride, Sky Village, Endless City in Height, one can see a different typology of high-rises representing mega structures of an autonomous urban ecosystem that can return more to the environment than they consume. [28]

\section{Conclusion}

The results of the study have made it possible to differentiate the existing regional approaches, connected with environment context, positioning and image of states, national 
self-identity, which reflected in architecture and spatial planning. The design of advanced high-rise objects is impossible without the eco strategies which solve regional problems. In large variety of completed objects, it is possible to single out the set of stylistic and tech methods in high-rise as well as basic missions preserved in the near future.

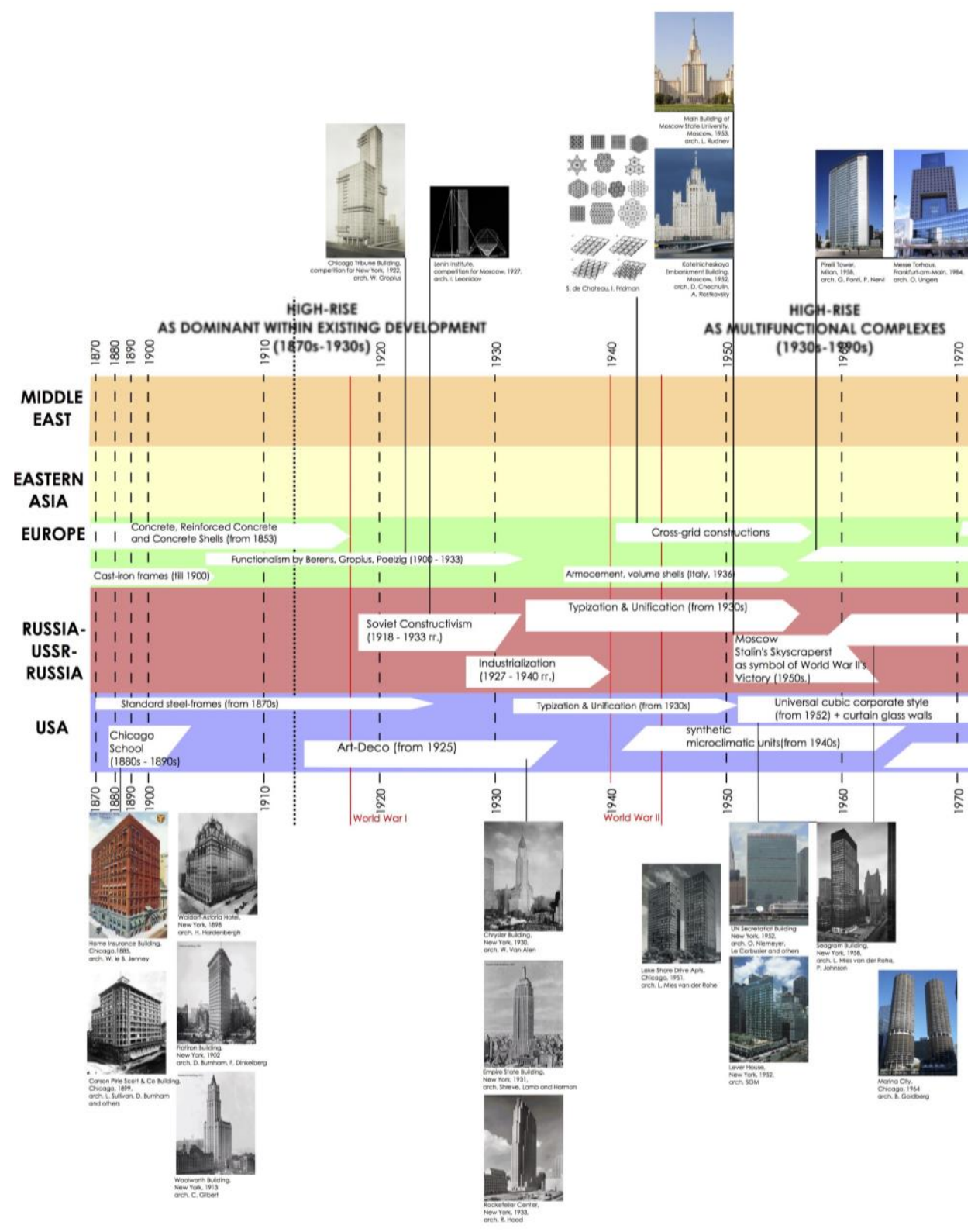

Fig. 1. Evolutionary Matrix of High-Rises by the Global Regions. Part1 

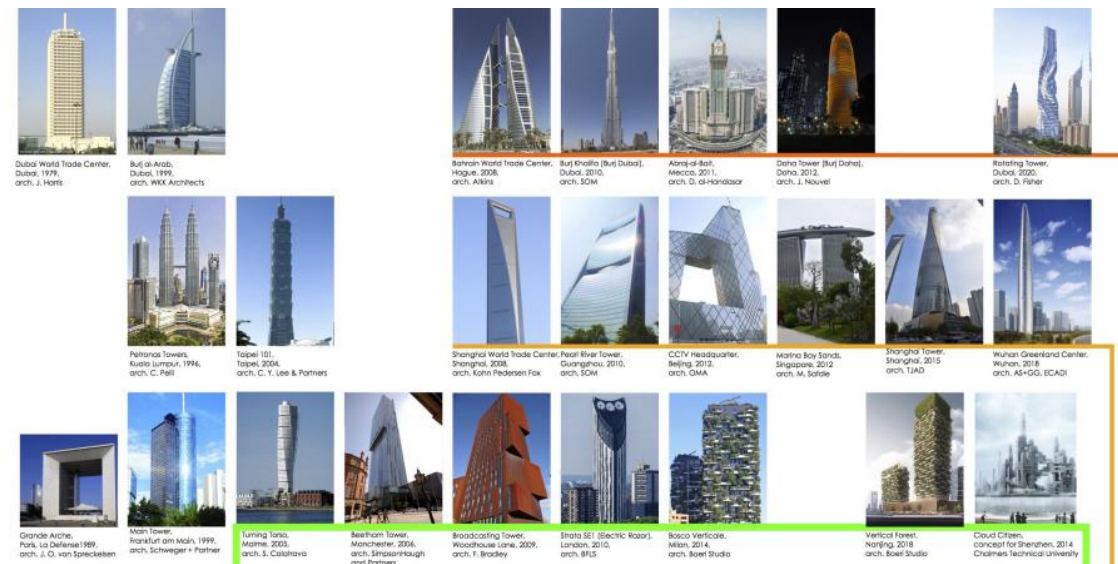

s.m
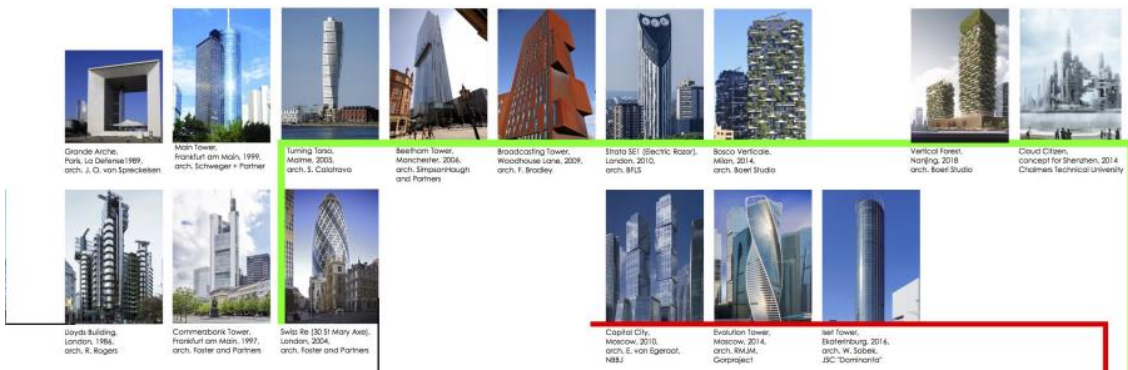

HIGH-RISE

AS CONCEPT OF BETIER MULTIFUNCTIONAL UVING

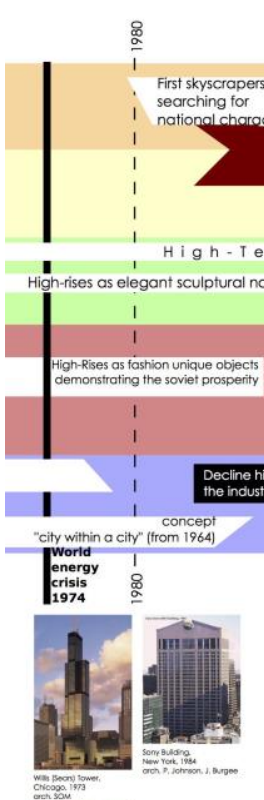

\&

Unique extraordinany objects Demonstration of economic prosperity

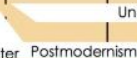

usiness centers Aftraction for tourists

Solution for overpopulated districts

Increasing high-r ses as business centers

Developing the concept of dense living

Way to eco living

Way to zero energy consumption

Scientific polygon to develop

advanced engineerings

Aspiration to fix within the full-fledged

participants of the world economy

Demonstration of economic renaissance

Apartments for billionaires

("Super-Slenders", "Courtscrapers")
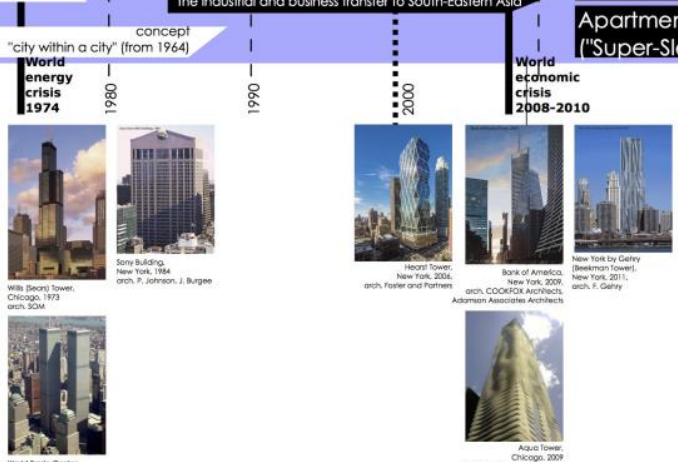

ind
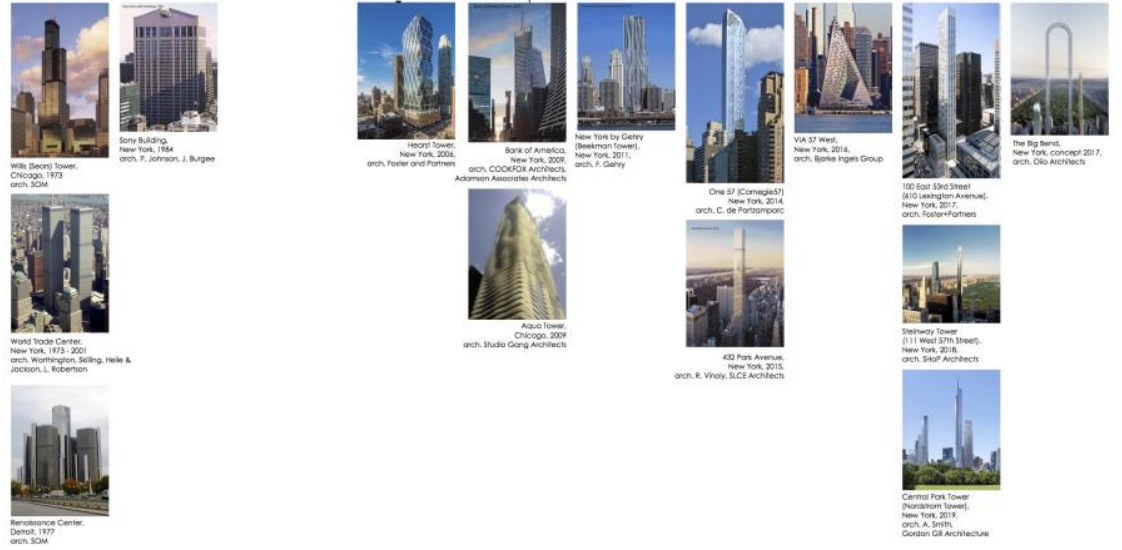

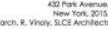

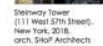

Fig. 2. Evolutionary Matrix of High-Rises by the Global Regions. Part2 
High-rises as symbols. The birth of each new skyscraper is a unique event. Unique highrise buildings have become not only the symbols of their countries, but revolutionize in the field of architecture and engineerings, as Burj Khalifa, for example. Here they are: Swiss Re, London; Torre Agbar and Porta Fira in Barcelona; Burj Qatar in Doha; Shanghai Tower; Absolute World Towers in Toronto; Capital Gate in Abu-Dabi, Makkah Clock Royal Tower in Mecca and hundreds of other in row.

High-rises as advanced tech solutions. The priority of energy efficiency in modern highrise is provided by optimal space-planning solution and energy-efficient engineering and materials. The smallest perimeter, for example, with the common useful area, leads to a reduction in heat and streamlining forms. The appearance of "super-slenders" with a base of up to $12 \mathrm{~m}$ and a high flexibility of the structures shows how compact a high-rise building plan can be. Atrium spaces allow us to save on heating and create a natural environment within. Amazing twisting forms with different floor shifts is justified by the reduction of aerodynamic loads and makes them spectacular objects. Designing streamlines, it is possible to minimize the wind effect. Objects of high-rise construction are a field for the modern facade systems. One of the most popular techniques has been the use of membranes, which give sculptural freedom. There is a revolution from traditional methods to information techs, among them is BIM (Building Information Modeling) technology.

\section{Acknowledgments}

Special thanks to professor V.P. Generalov - Head of the department ARPB in Samara State Tech University and assistant professor E.M. Generalova for the promotion of advanced high-rise construction in the field of architectural education in Russia.

\section{References}

1. http://www.ctbuh.org/ (last accessed 02.05.2017)

2. http://www.som.com/ (last accessed 06.06.2017)

3. T. G. Maklakova, High-Rise Buildings, Urban and architectural-structural problems in design, Monography 2nd edition, supplemented, 160 (Moscow, ASV, 2008)

4. http://tallbuildings.ru (last accessed 12.05.2017)

5. Y. A. Tabunshikov, From Energy-Efficient to Life-Retaining Buildings, 3, 8 (AVOK, 2003)

6. Y. A. Tabunshikov, Energy-Efficient Buildings, 8-76 (Moscow, AVOK-Press, 2003)

7. M. M. Brodach, HIgh-Rise Engineerings, 320 (Moscow, AVOK-Press, 2007)

8. Kheir Al-Kodmany, Green towers and iconic design: Cases from Three Continents, International Journal of Architectural

9. Ahmad Rahimian, Yoram Eilon, New York's Hearst Tower. A Restoration, an Adaptive Reuse and a Modern Steel Tower Rolled Into One, Structure magazine, 2, 25-29 (2006)

10. https://courses.cit.cornell.edu/crp384/2008reports/18Green_Skyscrapers (last accessed 12.05.2017)

11. E. M. Generalova, V. P. Generalov, Super-slender residential skyscrapers in New York as a new direction in high-rise buildings typology, Urban construction and architecture, 4(25), 85-91 (2016) DOI: 10.17673 Vestnik.2016.04.16.

12. https://static.dezeen.com/uploads/2016/06/new-york-super-slenderskyscrapers_dezeen_large.jpg (last accessed 11.05.2017) 
13. http://www.fosterandpartners.com/Projects/1405/Default.aspx 23 November 2017

14. htt://web.utk.edu/ archinfo/a489_f02/PDF/commerzbank.pdf (last accessed 30.05.2017)

15. https://www.stefanoboeriarchitetti.net/en/portfolios/taranto-calling-2/ (last accessed 30.05.2017)

16. https://www.kpf.com/ (last accessed 26.05.2017)

17. http://www.som.com/content.cfm/pearl_river_tower (last accessed 26.05.2017)

18. http://members.ctbuh.org/shanghai-tower-construction-development (last accessed 26.05.2017)

19. www.stefanoboeriarchitetti.net/en/portfolios/sustainable-dystopias/ (last accessed 25.04.2017)

20. I Richards, T. R. Hamzah \& Yeang: ecology of the sky (The Millennium Series) Images, 247 (Australia, 2001) ISBN 1864700955, 9781864700954

21. https://books.google.ru/books? $\mathrm{id}=\mathrm{QitFFq7Ybg0C \& printsec}=$ frontcover $\& h \mathrm{~h}=\mathrm{ru} \# \mathrm{v}=$ one page\&q\&f=false (last accessed 28.05.2017)

22. Generalova E., Generalov V. Designing High-Rise Housing: The Singapore Experience, CTBUH Journal, 4, 40-45 (Chicago, Illinois Institute of Technology, 2014)

23. http://grandengineer.ru/skyscrapers/one-central-park-luchshij-neboskreb-2014-goda/ (last accessed 06.05.2017)

24. http://www.jeannouvel.com/ (last accessed 06.05.2017)

25. http://skyrisecities.com/database/cities/dubai (last accessed 07.05.2017)

26. http://www.forum-100.ru/pressroom/vysotnoe-stroitelstvo-rossii-na-rubezhe-vekov/ (last accessed 12.05.2017)

27. http://www.jameslawcybertecture.com/ (last accessed 11.05.2017)

28. V. P. Generalov, E. M. Generalova The Perspectives to Develop New Types of HighRises. Urban Future, Vestnik SGASU, Urban Planning and Architecture, 1(18), 13-18 (2015)

29. http://www.archdaily.com/549665/cloud-citizenawarded-joint-top-honors-in-shenzhenbay-super-citycompetition/ (last accessed 12.05.2017)

30. http://oma.eu/ (last accessed 16.05.2017) 